\title{
Cenná monografie o české a srbské frazeologii
}

POPOVIĆOVÁ, S.: Česká a srbská frazeologie. Na cestě ke dvojjazyčnému frazeologickému slovníku. Praha: Univerzita Karlova 2020, 206 s. ISBN 978-80-246-4608-4, 978-80-246-4670-1 (pdf).

Předmětem výzkumu posuzované monografie Snežany Popovićové, docentky Katedry slavistiky Filologické fakulty Bělehradské univerzity, jsou české a srbské frazeologické teorie a frazémy v obou jazycích. Autorka si kladla za cíl porovnat definice a vlastnosti základní jednotky frazeologie, dále analyzovat frazeografickou praxi a v neposlední řadě navrhnout samotný slovník frazémů.

Monografie se skládá z předmluvy a ze sedmi kapitol, v nichž autorka zpracovává tematiku frazeologie a frazeografie způsobem, který nepochybně svědčí o autorčině hluboké znalosti této problematiky.

V první kapitole Frazeologická prolegomena ${ }^{1}$ autorka zasvěcuje čtenáře do problematiky frazeologie. Definuje oblast této disciplíny a představuje její rozvoj v české a srbské jazykovědě a její spojení s jinými disciplínami.

Druhá kapitola Frazém a idiom v české a srbské lingvistice je věnována frazeologické terminologii jako důležité komponentě konfrontačního výzkumu. Na základě rozboru používané terminologie $\mathrm{v}$ pracích srbských, českých, charvátských a slovenských lingvistů, autorka usuzuje, že by termín frazém a idiom, používaný v české lingvistice, obohatil a zpřesnil srbskou terminologii a vedl $\mathrm{k}$ jednoznačnosti při terminologickém vymezení z formálního a sémantického hlediska. Dále se autorka zabývá samotnými termíny a terminologií jako normativní disciplíny, a v závěru kapitoly také zkoumá kritéria pro kategorizaci frazémů.

Ve třetí kapitole Kombinatorika ve frazeologii ${ }^{3}$ pojednává S. Popovićová o kombinatorických schopnostech frazeologie a o formální klasifikaci frazémů. Zabývá se podrobně kombinatorikou na úrovni morfému, lexému a kolokací a věnuje pozornost lexikálním frazémům $\mathrm{v}$ češtině a srbštině. Př́ílady dělí podle způsobu tvoření na deriváty a kompozity, a dále podle ekvivalence do tří skupin, a to na ty, které mají idiomatické ekvivalenty v českém, resp. srbském jazyce, dále na ty, které jsou bez idiomatického ekvivalentu v češtině, a pak na takové, které nemají idiomatický ekvivalent v srbštině.

1 POPOVIĆOVÁ, S.: Česká a srbská frazeologie. Na cestě ke dvojjazyčnému frazeologickému slovníku.

Praha: Univerzita Karlova 2020, s. 7-10.

2 Tamtéž, s. 11-28.

3 Tamtéž, s. 29-79. 
Z celkového počtu 347 lexikálních frazémů činí téměř polovinu ekvivalentní dvojice. Autorka pozoruje vysokou slovnědruhovou a slovotvornou shodu a na základě toho konstatuje kompletní idiomatičnost: sémantickou, formální a derivologickou.

V této rozsáhlé kapitole je zahrnuta také analýza ustálených kolokací a kolokačních frazémů $\mathrm{v}$ češtině a srbštině. Na základě rozboru binárních kombinací $\mathrm{v}$ obou jazycích zjištuje, že čeština má poněkud vyšší kombinatorickou schopnost tvoření synsémantik, ale že nejde o významný rozdíl, zatímco kolokace smíšené ukazují více rozdílů mezi dvěma jazyky - větší kombinatorické schopnosti u verb a partikulí jsou v češtině, srbština naopak má o něco početnější kombinace s numeráliemi. Dále autorka představuje postoje $\mathrm{k}$ propozičním frazémům nejen srbských a českých lingvistů, ale i charvátských, ruských, anglických a slovenských představitelů frazeologické disciplíny a pojednává o expresivitě, emocionalitě a o funkci frazémů. Stranou nezůstaly ani tautologické výrazy, jejichž ustálenost a uzuálnost zdůrazňuje autorka na základě př́kladů ze čtyř slovanských jazyků.

Čtvrtá kapitola Frazeografie 4 se týká oblasti aplikované frazeologie. S. Popovićová v ní důkladně rozebírá srbské a české tištěné i elektronické zdroje, uspořádání hesla ve frazeologických slovnících, a také zdůvodňuje náměty vedoucí k vytvoření překladového frazeologického slovníku.

Po páté kapitole Závěrem aneb Hledání společného jazyka ${ }^{5}$, ve které S. Popovićová sumarizuje poznatky, k nimž došla na základě kontrastivní analýzy české a srbské frazeologie a frazeografie, následuje kapitola Česko-srbský frazeologický somatický slovník ${ }^{6}$, jež shrnuje jak autorčino dosavadní lexikografické bádání, tak její postoje zastávané $\mathrm{v}$ této monografii.

Slovník představuje somatické frazémy současného českého jazyka a jejich ekvivalenty v srbštině. Obsahuje 1641 heslovou stat', nicméně celkový počet frazémů činí, díky tomu, že autorka do něj zařadila také česká synonyma a antonyma, přes 4 ooo. Materiál je excerpován ze slovníků uvedených v sedmé kapitole Použitá literatura, prameny a $z d r o j e^{7}$, a to ze všech dostupných výkladových frazeologických slovníků českého, srbského a charvátského jazyka, dále z překladových česko-srbských a srbsko(srbocharvátsko)-českých slovníků, a z překladových frazeologických slovníků jiných slovanských jazyků. Nechybí ani prameny jako jsou Český národní korpus a Korpus současného srbského jazyka, odborná literatura a konečně i vlastní výzkum, který autorka provedla mezi českými a srbskými mluvčími. Do slovníku zařadila jak kolokační, tak propoziční frazémy, a po jejich formální stránce jde o přirovnání,

4 Tamtéž, s. 80-112.

5 Tamtéž, s. 113-115.

6 Tamtéž, s. 116-20o.

7 Tamtéž, s. 201-206. 
neslovesné výrazy, jakož i o výrazy slovesné a větné. Heslová stat’ obsahuje frazém v češtině, stylovou charakteristiku, údaj o transformaci, výklad významu v srbském jazyce, srbský ekvivalent, údaje o úzu nebo původu frazému, exemplifikaci a synonyma a antonyma v češtině.

Monografie Snežany Popovićové je zatím nejpodrobnějším kontrastivním porovnáním moderní české a srbské frazeologie v srbském prostředí. Jako taková, představuje cenný prrínos $\mathrm{k}$ česko-srbské frazeologii a frazeografii vytvořením a představením teoretických východisek ke zpracování frazeologického slovníku a detailním rozborem podloženým četnými př́iklady frazeologických jednotek a jejich ekvivalentů. Její nesporný význam spočívá v autorčině česko-srbském slovníku somatismů, vzhledem $\mathrm{k}$ tomu, že podobný dosud nebyl vytvořen, jež je však i úvodem do překladového česko-srbského frazeologického slovníku, který autorka již připravuje. Je také nepostradatelnou literaturou ve výuce srbštiny a češtiny v Srbsku a České republice, užitečnou pomůckou v překladatelské praxi, a také zajímavou četbou pro všechny zájemce o frazeologii a frazeografii.

Katarina Mitrićević-Štepanek

\section{Literatura:}

POPOVIĆOVÁ, S.: Česká a srbská frazeologie. Na cestě ke dvojjazyčnému frazeologickému slovníku. Praha: Univerzita Karlova 2020, 206 s. ISBN 978-80-246-4608-4, 978-80-246-4670-1 (pdf). 